\title{
Determination of economically viable option of liquidation the consequences of external dump deformation
}

\author{
Yevheniy Babets ${ }^{1}$, Oleh Anisimov ${ }^{2}$, Oleksandr Shustov ${ }^{2,}$, Vitalina Komirna $^{3}$, and Iryna Melnikova ${ }^{4}$ \\ ${ }^{1}$ Scientific-Research Mining Institute of the Kryvyi Rih National University, 57 Gagarin Ave., Kryvyi Rih, 50086, Ukraine \\ ${ }^{2}$ Dnipro University of Technology, Department of Surface Mining, 19 Dmytra Yavornytskoho Ave., Dnipro, 49005, Ukraine \\ ${ }^{3}$ European Social andTechnology University, Faculty of Sociomedical Sciences, 13/21 Wodna St., Radom, 26-600, Poland \\ ${ }^{4}$ Kryvyi Rih National University, Department of Management and Administration, 11 Vitaliy Matusevych St., Kryvyi Rih, 50027, \\ Ukraine
}

\begin{abstract}
The safety factors for different variants of operation development were obtained, on the basis of which the technical and economic indicators were established and the most expedient way of restoration of dump operations in conditions of the formed landslide was chosen. The solutions were proposed for the external dump No 2 of the Central Ore Mining and Processing Enterprise (COMPE), that allow to continue its future operation. When working in the conditions of the formed landslide, three variants of the further dump operation are modeled: the first one - with landslide removal and unloading of the upper dump horizons, the second one - without landslide removal and involvement of disturbed lands in land allotment, the third one - with the landslide loading. Based on the built sections of the dump and defined physical and mechanical properties, the stability factors were obtained for different options of the operation development, which made it possible to determine the appropriate option to eliminate the effects of the dump slide deformations. As a result of the calculations, the cost flows for each of the proposed options of the formation of the end contour of the dump No 2 are determined.
\end{abstract}

\section{Introduction}

Practice and scientific research show that the overburden rocks during the development of deep open mines are stored in external dumps, which occupy large areas. Their systematic expansion and considerable distance from the open mines lead to a significant increase in the cost of field development as a whole. To place the dumps, in some cases, hollows and ravines are used, which are almost impossible to use in agriculture. When storing overburden rocks in such conditions, it should be accounted that the weight of the dump placed in the hollows effect the base and can lead to deformation of the sides. Such processes can be facilitated by the presence of ground and surface water, which moisten the rocks of the dump base. The formation of such deformations, as a rule, occurs outside the land allotment of the enterprise. In this regard, there are unforeseen costs to eliminate the effects of deformation, which in difficult economic conditions and reducing demand for iron ore concentrate is unacceptable.

\section{Analysis of studies}

The development of deep open mines in Ukraine is accompanied by the placement of overburden rocks in external dumps. Issues of dump formation have been considered in various scientific papers [1-8]. The volume of the overburden rocks extraction of and their storage in the external dump directly depends on the productivity of the open mine where minerals are extracted [9-17]. The placement of overburden rocks and the productivity of open mine equipment is an important task that affects the sequence of dump development and the stability of slopes. Many scientific works consider methods of strengthening berms and ledges and methods of construction of potential sliding surfaces and calculations of strengthening parameters, which is confirmed by considerable experience in strengthening unstable surfaces. Problems of stability of slopes of quarries and dumps were considered in many scientific works [18-21]. Solving the problem of stability makes it possible to increase naturally or artificially the safe operation of external and internal dumps.

\section{Problem formulation}

The Dump No 2 of the PJSC Central Ore Mining and Processing Enterprise (excavator) is located at a distance of $12 \mathrm{~km}$ from the open mine in the OleksandroMaryivska hollow (Fig. 1). Loose and rock mass are stored in the dump, which are delivered by rail transport. In fact, the dump is poured in succession in several tiers. At the dump No 2, the overburden rocks is accepted at 2 dump dead ends and is dumped with the help of ECG-8I and EK 10/70 excavators. Overburden rocks in the dump

\footnotetext{
* Corresponding author: shustov.o.o@nmu.one
} 
No 2 of the PJSC "COMPE" is delivered from the faces and reloading points of the open mine No 3 . The transport development system is used in this open mine.

As a result of the landslide that occurred on the dump No2 of the Petrovsky open mine of the PJSC "COMPE",

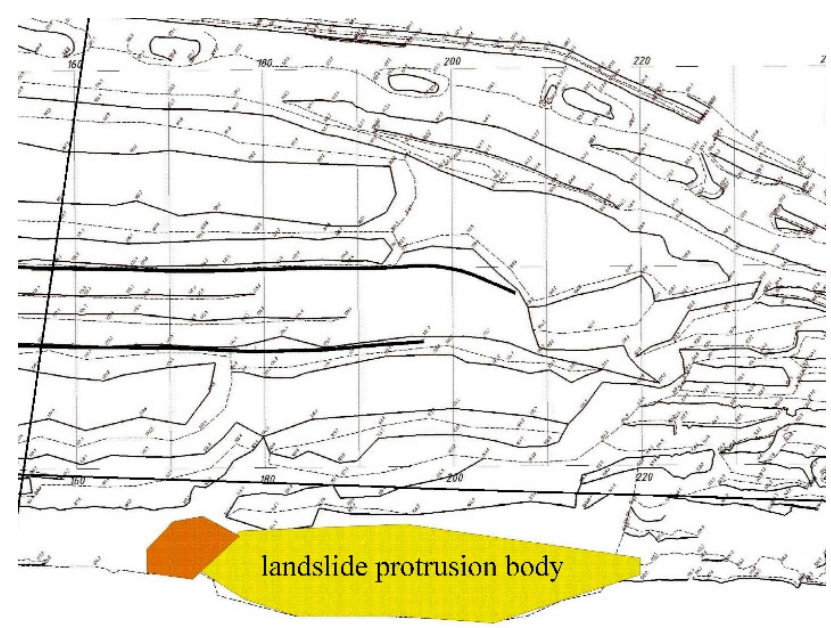

Fig. 1. Schemes of the formed landslide and placement of boreholes.

Deformations in the form of landslide with the following parameters appeared on the section of the south-western side of the dump No 2: the length of the landslide manifestation was $410 \mathrm{~m}$; the depth on average was $7 \mathrm{~m}$; the volume was 850 thousand $\mathrm{m}^{3}$; landslide area is 85 thousand $\mathrm{m}^{2}$. It should be noted that previously no deformations were observed in this part of the dump. In the area of the dump formation there is a complex relief with a hollow. The negative aspects include the very low strength of rocks placed into the dump (mainly clays, loams), which have a high plasticity at a natural humidity of $21-25 \%$, the sole of which also contains different by their physical and mechanical properties loams.

Therefore, the following tasks need to be solved: using geophysical methods to determine the presence of aquifers and their impact on the dump, to consider possible options for the development of works on the dump taking into account the formed deformations, to determine the stability of slopes according to the proposed models of development, to choose the best technical and economic indicators.

\section{Purpose}

To solve the tasks it is necessary to determine the most economically feasible option for the development of works on the dump where the processes of landslide deformation and protrusion in its sole outside the land allotment of the enterprise.

\section{Methodology}

To solve the tasks set force in this work, the following research methods were used: geophysical method of the Earth's natural pulsed electromagnetic field (NIEMEF) for the forecast estimation of the risk of formation of new centers of geodynamic phenomena and development of the measures to prevent them; the method of algebraic
1.42 hectares of arable land were disturbed. There was a need to take measures to eliminate the effects of the landslide. In this regard, options for further dump operation were considered.

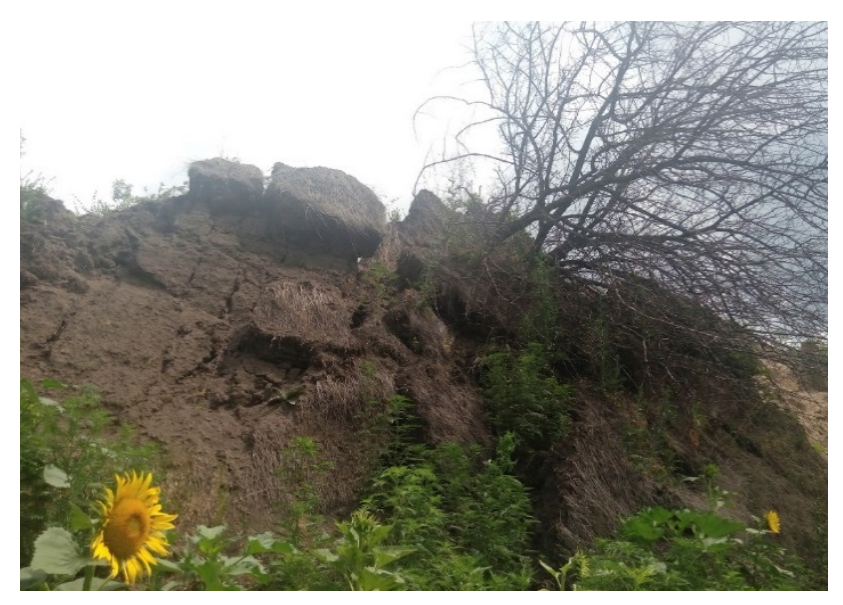

addition of forces - to establish changes in the stress-strain state of the rock array; computer modeling to substantiate technological solutions by options; graphical and analytical method - to calculate the stability of slopes by various options of the development of mining operations on a dump; economic comparison of accepted technological decisions - to define a rational variant of formation of the final dump contours.

\section{Selection of initial data}

The boundary of the dump No 2 is within the hollow and the dump occupies its entire area (see Fig. 1). The body of the protrusion in the plan is a complex isometric figure, the length of which is $490.6 \mathrm{~m}$, and the maximal width from the outer boundary (on the arable field) to the boundary of the joint behind the sole of the protrusion with the ledge of the dump $111.9 \mathrm{~m}$. The protrusion surface is presented by the complicated relief with atypical height differences complicated by violations (cracks). The body of the protrusion has: 46 thousand $\mathrm{m}^{2}$ - the area of the base of the body of the three-dimensional model of the protrusion; 700 thousand $\mathrm{m}^{3}$ is the volume of protrusion. In addition, there is a scree formed to the west of the protrusion due to a violation of the density of the ledge when moving rocks during the protrusion. It has the form of a dump ledge with an average height of $25 \mathrm{~m}$ and a length of $82.6 \mathrm{~m}$, and a width of $78.5 \mathrm{~m}$. The area of the scree base made 6.5 thousand $\mathrm{m}^{2}$. The total volume (talus and protrusion) amounted to 850 thousand $\mathrm{m}^{3}$.

Geo-mechanical studies of changes of the stress-strain state in the studied area were conducted in order to forecast the risk of formation of new centers of geodynamic phenomena and develop measures to prevent them. The geophysical method of the natural pulsed electromagnetic field of the Earth (NPEMEF), which was applied, is used in engineering and geological research to clarify the localization of processes and phenomena 
occurring [22]. An example of interpretation of measurement results is shown in the Fig. 2.

The rocks that form the basis of the dump: the modern division $\left(q_{i v}\right)$ is represented by a soil-vegetation layer with a thickness of $0.1-0.5 \mathrm{~m}$, upper quaternary sediments $q_{i}$ are represented by two varieties: pale loams, pale yellow loess and brownish-yellow with the thickness of up to 4$4.5 \mathrm{~m}$; middle quaternary sediments $\mathrm{q}_{\mathrm{i}}$ are represented by two types of brown-pale and yellow-brown loams with a thickness of 0 to $8 \mathrm{~m}$; brown and red-brown clays, which belong to the undismembered neogene-quaternary sediments lie in the form of lenses with a thickness of 1.6 to $13 \mathrm{~m}$; below there are the primary kaolins with a thickness of 2.8 to $20 \mathrm{~m}$.

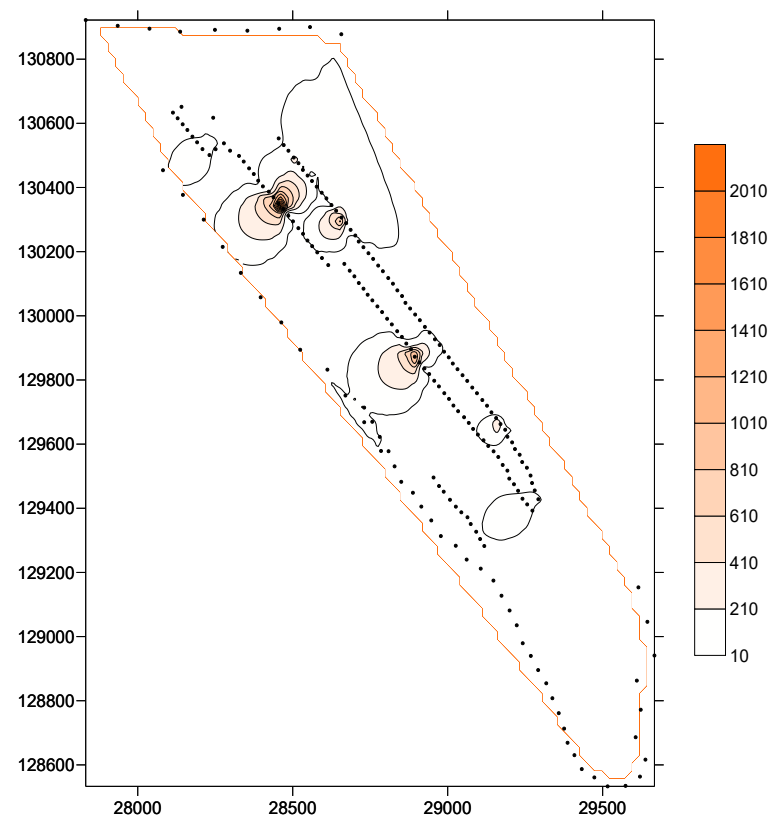

Fig. 2. Example of site interpretation of the study results using the NPEMEF method for creep zone (sliding rocks) at the dump No 2 in the $\mathrm{Z}$ plane (Color scale in $\mathrm{mV}$ )

\section{Organization of calculations}

As a result of geophysical studies of the dump No 2 of the Petrovsky open mine of the PJSC "COMPE" by the method of NPEMEF the following was established: the north-eastern side of the dump is currently stable, so the following description applies to the south-western side; cracking in the rock mass of the dump at the time of the study mainly occurs in the northern part; areas of rock landslides at the time of research are established in the northern part and in the area of deformation; the stressstrain state of the rock mass of the dump №2 is registered in the south-western section and at the workplaces of the equipment in the middle part of the dump; water migration is superficial; the groundwater mirror in some areas is in the range from 1.5 to $10 \mathrm{~m}$; deep accumulation of moisture is not observed, as the modern and ancient relief promote drainage, and inflows of surface waters should be regulated by means of the water drainage channel.
The direction of groundwater migration along the axis of the hollow from the north to the south. It should be noted the possible presence of lenticular accumulations of water in the northern and middle part of the dump. The accumulation of groundwater in such lenses can lead to landslides in these areas.

To determine the stability of the dump the method is used proposed by the institute "VIOGEM". From the upper edge of the slope shown in the Figure 3 in one of the scales adopted for surveying documentation, the value of the width of the slide prism $a$ and the vertical value of $H_{90}$ are set.

Studies have shown that the sliding surface of the slide prism for these conditions is smooth curvilinear, the form of which is close to round-cylindrical. The location of the most stressed surface in the rock mass adjacent to the slope coincides with the location of the calculated surface with a minimum safety factor. This surface is defined by stability calculations. Taking into account the obtained physical and mechanical properties of rocks, as well as when testing wells, it became clear that the rocks are not flooded. Therefore, the calculation is carried out under condition of limit equilibrium of forces.

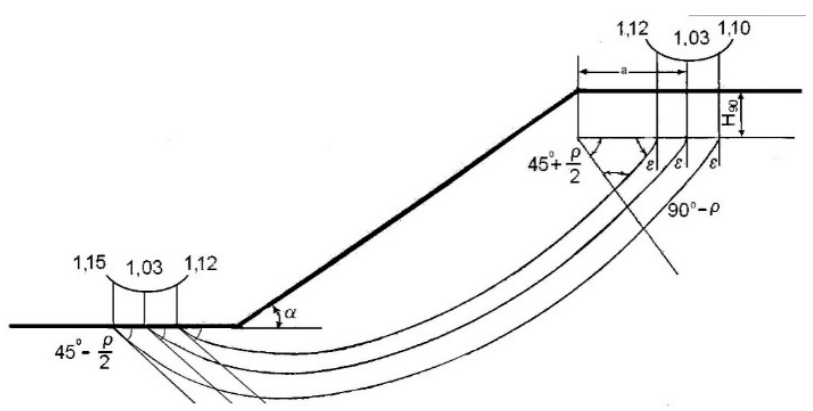

Fig. 3. The position of the calculated surfaces on the slope of weak rocks $\left(\rho<13^{\circ}, \alpha<\varepsilon\right)$

The condition of limit equilibrium in the algebraic addition of forces on the most stressed surface is written as follows:

$$
\frac{\sum_{i=1}^{n} P_{i} \cos \varphi_{i} \cdot \operatorname{tg} \rho_{n}+\sum_{i=1}^{n} k_{n} l_{n}}{\sum_{i=1}^{n} P_{i} \sin \varphi_{i}}=\frac{\operatorname{tg} \rho_{n} \sum_{i=1}^{n} N_{i}+k_{n} L}{\sum_{i=1}^{n} T_{i}}(1)
$$

where $P_{i}$ - the weight of the elementary blocks into which the prism is divided in the array, adjacent to the slope, limited by the most stressed surface, $t$;

$l_{i}$ - square of the base of elementary blocks, $\mathrm{m}^{2}$;

$\varphi_{i}$ - incline angle of the base of elementary blocks, degrees;

$\rho_{n}, k_{n}$ - features of resistance of sliding rocks, decreased by $n$ times.

\subsection{Options of the dump forming schemes}

During the work performance it is offered to consider 3 variants of the decision of unscheduled works on the landslide liquidation (fig. 4).

Option 1. Removing the landslide to the boundaries of the land allotment without allocating of additional land and determining the possibility of further storage the overburden rocks in this area (Fig. 4). 
Option 2. To carry out land allotment on the slide section from slide action and to define possibilities of the further of overburden rocks in conditions of the formed landslide on the dump (Fig. 4).

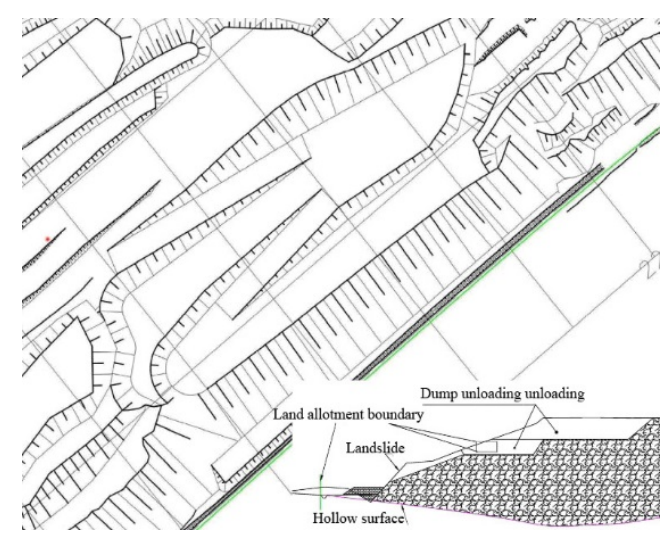

Option 1
Option 3. To carry out land allotment on a slide section in conditions of the formed landslide on the dump, to form a support prism from slide action and to define possibilities of the further storage of the overburden rocks (Fig. 4).

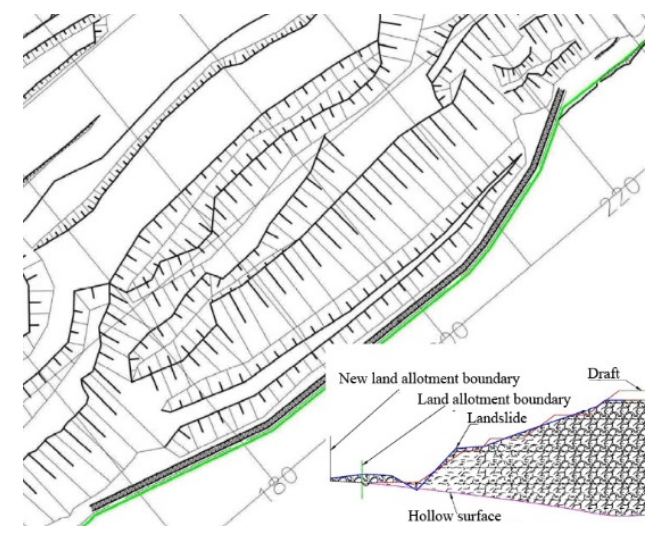

Option 2

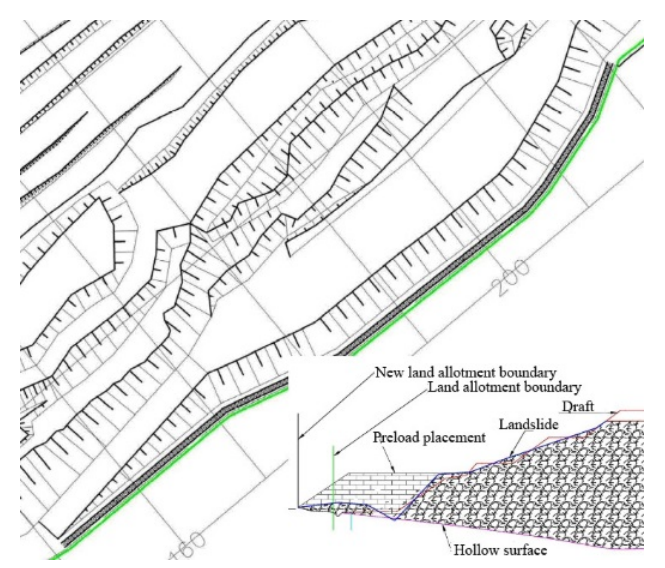

Option 3

Fig. 4. Technological schemes of the options for solving the problem of landslide.

Taking into account the determination of the residual capacity of the dump No 2, calendar plans for storage of the overburden rocks have been developed according to the options (Fig. 5), in thousand $\mathrm{m}^{3}$.

\section{Placing overburden rocks by years}

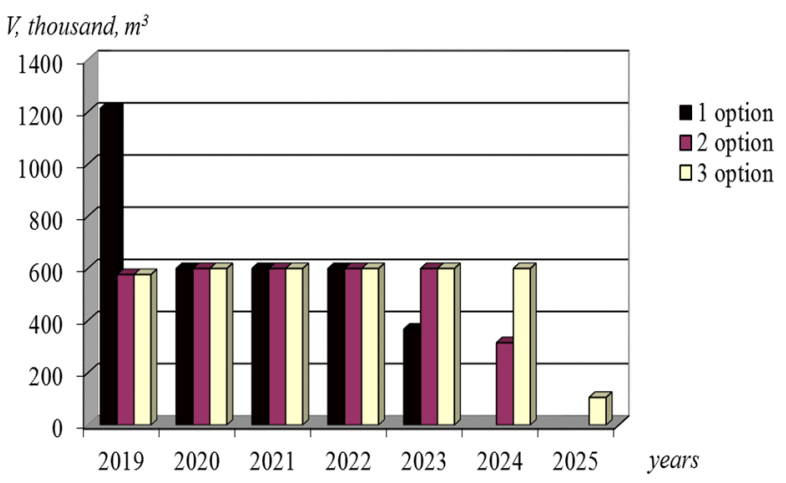

Fig. 5. Placing overburden rocks by years at the dump according to the work development options

\subsection{Calculation of stability parameters}

For different variants, taking into account the obtained sections, the safety factors were set. The calculation scheme for the option 3 is shown in the Fig. 6. Calculations were reduced to the search for sliding forces and restraint forces.

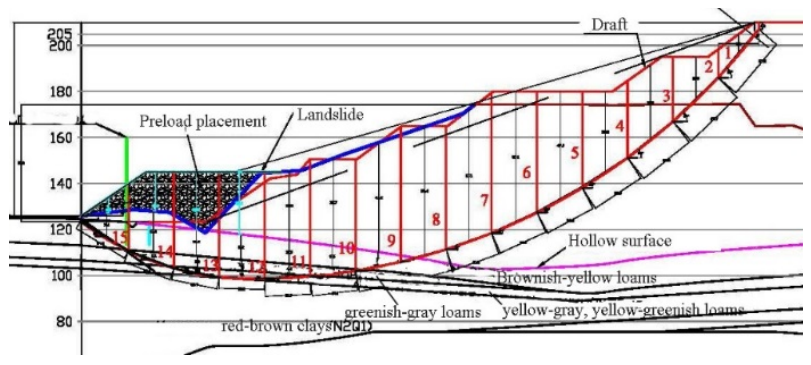

Fig. 6. Graphic part of the calculation of stability in the section surveying axis (s.a.) 180 (with loading)

At the initial stage, the following data on the safety factor were obtained (table 1) around the perimeter of the whole dump. 
Table 1. Summarized table of the safety factors

\begin{tabular}{|l|c|c|c|c|c|}
\hline & $\begin{array}{c}\text { Current } \\
\text { position }\end{array}$ & $\begin{array}{c}\text { After slide } \\
\text { removal }\end{array}$ & Draft state & $\begin{array}{c}\text { Draft state with the loading } \\
\text { by rock }\end{array}$ & $\begin{array}{c}\text { Draft state with } \\
\text { loading }\end{array}$ \\
\hline $\begin{array}{l}\text { Open mine 180(well PO-2, } \\
\text { slide) }\end{array}$ & 1.1 & 1.01 & 1.0 & 1.3 & 1.26 \\
\hline Open mine 180(well PO-7) & 0.71 & - & 0.99 & - & 1.18 \\
\hline $\begin{array}{l}\text { Open mine210(well PO-3, } \\
\text { slide) }\end{array}$ & 1.24 & 1.06 & $\begin{array}{c}\text { Almost current } \\
\text { state }\end{array}$ & 1.49 & 1.42 \\
\hline Open mine 210 (well PO-6) & - & - & 1.24 & - & - \\
\hline
\end{tabular}

Option 1 provides the removal of the landslide to the boundary of the land allotment. It is not possible to remve only landslide due to the reduction of the safety factor. To reduce the load on the dump, the option of removing a part of the rocks on the upper horizons between the marks +175 to $+160 \mathrm{~m}$ is considered. According to the calculation data the safety factor at the survey open mine 210 s.a. for the dump after removal of the rocks with the formation of the resulting slope $15^{\circ}$ makes 1.43 (Table 2). This figure is sufficient for a stable position.

When calculating the safety factor in the area between the marks +160.0 and $+124.0 \mathrm{~m}$, it was determined that this area is not stable $(\mathrm{Ky}=0.87$, Table 2$)$. That is, significant volumes of landsliding are possible in this area.

Table 2. Summarized table of the safety factors

\begin{tabular}{|l|l|l|l|l|}
\hline $\begin{array}{l}\text { Open } \\
\text { mine } \\
\text { s.a. }\end{array}$ & $\begin{array}{l}\text { The total stability of the dump } \\
\text { after removal of the upper tier } \\
\text { of the dump }(+174.0 \text { and }+ \\
160.0 \mathrm{~m}) \text { and bringing its slope } \\
\text { to } 15^{\circ}\end{array}$ & $\begin{array}{l}\text { Stability of the } \\
\text { lower tiers after } \\
\text { removal of the } \\
\text { upper tier }\end{array}$ & $\begin{array}{l}\text { The stability of the lower tiers } \\
\text { after removal of the second } \\
\text { tier }(+160.0 \text { and }+150.0 \mathrm{~m}) \\
\text { between s.a. } 180 \text { and s.a. } 190\end{array}$ & $\begin{array}{l}\text { Stability of the lower tiers after } \\
\text { removal of the second tier of the dump } \\
+160.0 \text { and }+150.0 \mathrm{~m}) \text { and backfill of } \\
\text { the support prism between s.a. } 180 \text { and } \\
\text { s.a. } 190\end{array}$ \\
\hline $\begin{array}{l}\text { s.a. } \\
210\end{array}$ & 1.43 & 1.34 & - & - \\
\hline $\begin{array}{l}\text { S.a. } \\
180\end{array}$ & 1.62 & $\mathbf{0 . 8 7}$ & $\mathbf{0 . 9 4}$ & $\mathbf{1 . 1 1 / * 1 . 2 4}$ \\
\hline
\end{tabular}

The area that is prone to slide in the open mine s.a. 180 (Fig. 4, option 1) is marked with cells. To reduce the pressure of the upper rocks in the area of $160 \mathrm{~m}$, it is necessary to remove a part of the rock mass on another horizon with marks from $+160,0$ to $+150.0 \mathrm{~m}$. However, the stability in the area increases only to a factor of 0.94 . Thus, this measure is also not enough. It is proposed to carry out backfilling with a prism at the base of this section after unloading the dump from the rocks of the upper horizons in the area between the surveying sections s.a. 180 and s.a. 190.

That is, according to the option 1, it is proposed to carry out a set of measures for removing the dump and return it in the boundaries of the land allotment in the area between the sections of the s.a. 180 and s.a. 190. Namely, the excavation of a part of the dump rocks in tiers with the marks of the first excavation tier +174.0 and $+160.0 \mathrm{~m}$ and the second tier in the area between the sections s.a.180 s.a. 190 with marks +160.0 and $+150.0 \mathrm{~m}$. To increase the safety factor, it is proposed to move the slide rocks to the base of the dump and form a support prism with an upper mark of $+129 \mathrm{~m}$. The height of the support prism is $9.0 \mathrm{~m}$. Landslide rocks are removed by excavator, are moved by auto dump trucks to the bottom of the dump and the supporting prism is formed by a bulldozer. The width of the top part of the prism is $20 \mathrm{~m}$. The safety factor in the area of the dump between the marks +1 K50.0 and +129 $\mathrm{m}$ will be 1.11 .
After removal of the part of the dump on the upper tiers where there was a landslide and the creation of a loading prism to the mark of $+129.0 \mathrm{~m}$ to ensure the normative stability of the dump is proposed to laying down on the section with a steep slope using an excavator EK-10/70. 2. The summarized table on the safety factors with the removal of the dump landslide and the return of the dump in the boundaries of the land allotment is given below.

\subsection{Recommendations for the obtained data on the stability of the dump slopes}

According to the performed mining and geological studies, the rocks at the base of the dump do not have groundwater.

The calculated values of the open mines (see Table 1) indicate that it is possible to remove the landslide, but this will reduce the stability of the dump. Thus, the safety factor in the open mine s.a.180 under the current position is 1.1 and after removal works, it will be 1.01 , which corresponds to the limit stability state. Thus, at some point the dump will be in a relatively stable state, but in the event of external factors, changes in the properties of the clays' rheologies at the base of the dump and in the dump, getting water and others, it will be prone to repeated landslides.

For open mine 180 in the area of drilling PO-7 will the stability adverse conditions will also appear. Measures to 
increase the stability is the reduction of the resulting slope inclination angle of the dump or the formation of the loading embankment at the base of the dump.

The data of the safety factor in the open mine 210 (Table 1) indicate that the current position in the sliding area of the dump is in a stable state (the safety factor is 1.24), after removal works this figure will decrease to 1.06 , i.e. the dump will be in a state of the limit equilibrium. At the moment of the slide removal at an unfavorable background (moisture, dynamic loadings, static loadings, change of clays' properties) repeated slide signs can appear. To increase the stability of the dump as well as when considering options for the open mine s.a. 180 it is proposed to load the dump in bulk at the base. The rocks removed from the open mine and stacked on the dump were taken into the calculations as the loading material.

Conclusions on the possibility of the option 1 (Table 2): It is proposed for removal the dump and returning it in the boundaries of the land allotment in the area between the sections of s.a. 180 s.a. 210 to implement a set of measures. To carry out excavation of waste rocks in tiers with the marks of the first excavation tier +174.0 and $+160.0 \mathrm{~m}$ and the second tier in the area between the sections of s.a. 180 s.a. 190 marked +160.0 and +150.0 m. To increase the safety factor, it is proposed to move the slide rocks to the base of the dump and form a supporting prism with an upper mark of $+129 \mathrm{~m}$ between the sections of s.a. 180 and s.a. 190, i.e. not along the entire length of the landslide, but only in the section with a length of approximately $160 \mathrm{~m}$. The safety factor in the area of the dump between the marks +150.0 and +129 m according to the calculations will be 1.11 . To increase the dump slope safety factor in the section, it is proposed to lay down the slope with an excavator EK-10/70. The EC excavator moves the rocks to the dump site with the mark $+160.0 \mathrm{~m}$, from where it is loaded into dump trucks with the help of an excavator and moved to the dump.

Option 1. Removal of the landslide, as well as the extraction of waste rock on the upper tiers is carried out by a hydraulic inverted shovel type excavator, and the laying down of the slope with EK excavator. Removal of the rock mass is carried out by the dump trucks to the dump where they are unloaded and placed by means of the bulldozer [23-25]. To remove the landslide, it is necessary to form a road, to lay down the power line and drive the EK excavator to the place of the landslide to the upper tiers. Landslide rocks are partially used to form the loading prism for this purpose a bulldozer must be used. When the landslide removal is finished with the help of an excavator, a trench of the water drainage ditch is formed and strengthening works are done with the placement of concrete slabs inside the ditch.

Option 2. The formed landslide remains within the existing limits. The works on construction a bypass ditch (see option 1) along the landslide with reinforcement works and the placement of concrete slabs are performed. Legislation regulates the issue of land allotment for the dump.

Option 3. The same works are performed as in the second option, but the road from the dump to the landslide is being reconstructed. A reloading point is organized at the dump. At the reloading point, the rock is shipped into dump trucks by an excavator and delivered to the landslide place. A pioneer embankment on the horizon of $+145 \mathrm{~m}$ is formed in the area of the landslide site. The formation of pioneer and loading embankments is done by a bulldozer. The rock mass delivered by dump trucks is unloaded on the loading embankment and formed by a bulldozer.

From the point of view of technological decisions the third option is most effective, which allows to place in addition volumes of overburden rocks both in a loading embankment ( 385.14 thousand $\mathrm{m}^{3}$ ), and to form a dump with a height within design contours providing the stability of the dump. Also, the technological solution is the formation of the dump with the landslide removal (option 1), for which it is first necessary to perform works to reduce the resulting slope angle by removing a part of the tiers of the dump and forming a loading prism at the base of the landslide.

Decisions on the effectiveness of options were made taking into account economic indicators.

To determine the economic indicators of options for the development of works on the dump the indicator PVI (Present Value of Investment) was used [26], which is calculated to obtain an idea of the current value of the total investment costs of the enterprise over the years. The decrease in this indicator against the background of an increase in discounted incomes from investments indicates an increase in their efficiency. The analytical expression of this indicator is as follows:

$$
P V I=\sum_{j=1}^{m} \frac{I_{j}}{(1+i)^{j}}
$$

where $I_{j}$ - annual investments during $m$ years.

To determine the amount of PVI per $1 \mathrm{~m}^{3}$ of the rock mass, the costs were reduced to the initial moment of time, taking into account the discount rate of $15 \%$. The reduced costs under the option 1 make only 68555.2 thousand UAH.

$P V I$ per $1 \mathrm{~m}^{3}$ of the rock mass will be: $68555.2 / 3381.675=20.27 \mathrm{UAH} / \mathrm{m}^{3}$

Thus, the net present investment costs under the first option will make $20.27 \mathrm{UAH}$ per $1 \mathrm{~m}^{3}$ of works related to the formation and reclamation of the dump.

Similar technical and economic indicators are determined under the 3 option. The net present costs under the option 3 make only 60081.03 thousand UAH. Thus, the net present investment costs under the option 3 will make $16.31 \mathrm{UAH}$ per $1 \mathrm{~m}^{3}$ of works related to the formation and reclamation of the dump. $60081.02 / 3682.985=16.31 \mathrm{UAH} / \mathrm{m}^{3}$

Given that the target criterion for the effectiveness of the investment options is to minimize the cost of dump formation, it is the option 3 should be considered as one that provides a more rational use of investment resources.

According to the results of calculations in the table 3 the technical and economic indicators for the formation of the final contour of the dump No 2 on the CO MPE are shown.

The main operating costs for the formation of the dump over the years are shown in the Fig. 7. 
Table 3. Technical and economic indicators

\begin{tabular}{|c|c|c|c|}
\hline \multirow{2}{*}{ Name of indicators } & \multirow{2}{*}{ Unit } & \multicolumn{2}{|c|}{ Value for development } \\
\hline & & \begin{tabular}{|l|} 
Option 1 \\
\end{tabular} & Option 3 \\
\hline 1. Dumping time & years & 5 & 7 \\
\hline $\begin{array}{l}\text { 2. Total volume of } \\
\text { overburden rocks stored }\end{array}$ & $\begin{array}{c}\text { Thousand } \\
\mathrm{m}^{3}\end{array}$ & 3381.675 & 3682.985 \\
\hline $\begin{array}{l}\text { 3. Mining and technical } \\
\text { reclamation: } \\
\text {-volume of cover soil }\end{array}$ & $\begin{array}{c}\text { Thousand } \\
\mathrm{m}^{3}\end{array}$ & 162.216 & 163.108 \\
\hline $\begin{array}{l}\text { 4. Biological reclamation: } \\
\text { - Furrowing; }\end{array}$ & & 185248.0 & 195232.0 \\
\hline $\begin{array}{c}\text { Number of seedlings } \\
-\quad \text { trees }\end{array}$ & s.a., units & 63577 & 67005 \\
\hline - $\quad$ bushes & & 15578 & 16418 \\
\hline 5. Mineral fertilizers & $\mathrm{kg}$ & 6883 & 7260 \\
\hline $\begin{array}{l}\text { 6. Irrigation water during } \\
\text { planting }\end{array}$ & $\mathrm{m}^{3}$ & 1030 & 1086 \\
\hline $\begin{array}{l}\text { 7. Water for vegetative } \\
\text { irrigation }\end{array}$ & $\mathrm{m}^{3}$ & 4122 & 4344 \\
\hline $\begin{array}{l}\text { 8. Capital investments for } \\
\text { the dump formation: }\end{array}$ & $\begin{array}{c}\text { Thousand } \\
\text { UAH }\end{array}$ & 22792.752 & 15696.563 \\
\hline $\begin{array}{l}\text { 9. Operational costs } \\
\text { - for mining and technical } \\
\text { reclamation; } \\
\text { - for biological. }\end{array}$ & $\begin{array}{l}\text { Thousand } \\
\text { UAH }\end{array}$ & $\begin{array}{l}15152.125 \\
11505.066\end{array}$ & $\begin{array}{l}15763.871 \\
12150.998\end{array}$ \\
\hline $\begin{array}{l}\text { 10. Agricultural } \\
\text { production costs }\end{array}$ & $\begin{array}{c}\text { Thousand } \\
\text { UAH }\end{array}$ & 150.480 & 150.480 \\
\hline $\begin{array}{l}\text { 11. Net present total } \\
\text { operating costs }\end{array}$ & \begin{tabular}{|c|}
$\begin{array}{c}\text { Thousand } \\
\text { UAH }\end{array}$ \\
\end{tabular} & 68555.2 & 60081.02731 \\
\hline $\begin{array}{l}\text { 12. Total net present } \\
\text { investments per } 1 \mathrm{~m}^{3} \text { for } \\
\text { forming and reclamation } \\
\text { of the dump }\end{array}$ & UAH & 20.27 & 16.31 \\
\hline
\end{tabular}

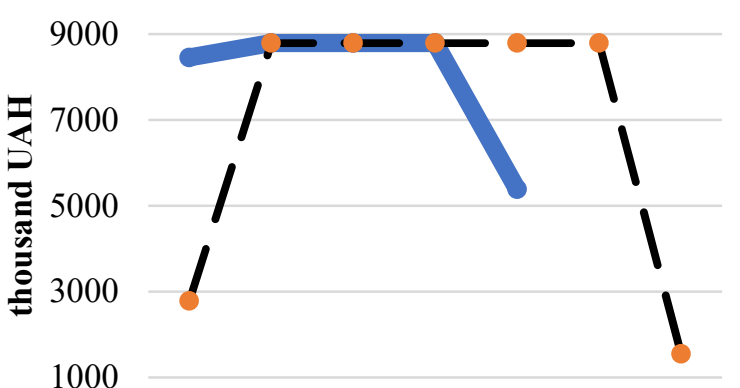

2019202020212022202320242025

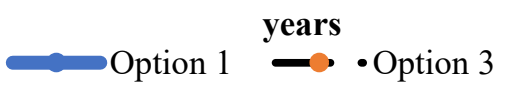

Fig. 7. Costs under the chosen options of the rock storage on the dump

\section{Conclusions}

1. As a result of the research of the dump No 2 of the Petrovsky open mine of the PJSC "COMPE" the following was established: the north-eastern side of the dump is currently stable, so the further description applies to the south-western side; cracking in the rock mass of the dump at the time of the study mainly occurs in the northern part; water migration is superficial.

2. During the operation of water-bearing communications (gutters) and the lack of the proper surface drainage, it is possible to soak the loess loams, which will reduce the deformation, strength characteristics and subsidence of the base soils, and as a consequence, negative processes of the rock mass extrusion [27-30].

3. Removal of the dump landslide to the boundaries of the land allotment can lead to repeated manifestations of rock slide. The dump will be in limit equilibrium, which is dangerous for machinery and people working at the bottom of the dump [31-34].

4. When forming the dump taking into account the formed landslide, there are two solutions for the further construction: the first one is the reduction of the dump height with observance of the angle of the resulting slope within 16 degrees and the second - construction of loading embankments in the formed landslide area. Loading embankments reduce the resulting angle and create additional load for the retaining forces.

5The calculation of costs for the formation of the final contours of the dump No 2: calculated costs for the creation of a drainage ditch, the land allocation costs, as well as operating costs for the formation of the main dump and its reclamation. It can be seen from the above calculations that the capital costs under the option 1 exceed the capital costs under the option 3 by 6918.549 thousand UAH. However, operating costs for the formation of the dump and the cost of reclamation are lower by 4434.19 thousand UAH and 1257,678 thousand UAH respectively. In order to be able to compare the costs of the projects, the net present investment costs for each of them are related to the formation and reclamation of the dump. Calculations have shown that the unit costs under the option 3 are UAH 3.96 less than the same indicator under the option 1. Thus, according to the criterion of minimizing the unit costs for the formation and reclamation of the dump No 2, the option 3 is more appropriate for implementation.

\section{References}

1. O.O. Anisimov, Nauk. Visn. Nat. Hirn. Univ. 1, $27-$ 34 (2018). doi:10.29202/nvngu/2018-1/17

2. S. Moldabayev, A. Adamchuk, N. Sarybayev, A. Shustov, in Proceedings of the International Multidisciplinary Scientific GeoConference Surveying Geology and Mining Ecology Management (2019), pp. 331-338. doi:10.5593/sgem2019/1.3/S03.042

3. B. Yu. Sobko, O.V. Lozhnikov, A.M. Haidin, O.M. Laznikov, Nauk. Visn. Nat. Hirn. Univ. 6, 41-49 (2016)

4. S. Moldabayev, B. Rysbaiuly, Z. Sultanbekova, N. Sarybayev, E3S Web of Conferences 123, 01049 (2019). doi:10.1051/e3sconf/201912301049

5. V. Symonenko, L. Hrytsenko, O. Cherniaiev, Min. of Miner. Dep. 10 (4), 68-73 (2016). doi: $10.15407 / \operatorname{mining} 10.04 .068$

6. K. Rysbekov, A. Toktarov, T. Kalybekov, S. Moldabayev, T. Yessezhulov, G. Bakhmagambetova, E3S Web of Conferences 168, 00016 (2020). doi:10.1051/e3sconf/202016800016 
7. T. Kalybekov, K. Rysbekov, M. Sandibekov, Y.L. Bi, A. Toktarov, Min. of Miner. Dep. 14 (2), 59-65 (2020). doi:0.33271/mining14.02.059

8. A. Mustakhimov, A. Zeynullin, Min. of Miner. Dep. 14 (3), 71-77 (2020).doi:10.33271/mining14.03.071

9. Ye.K. Babets, O.P. Bielov, O.O. Shustov, T.V. Barna, A.A. Adamchuk, Nauk. Visn. Nat. Hirn. Univ. 6, 36-44 (2019).doi:10.29202/nvngu/2019-6/6

10. V. Lozynskyi, V. Medianyk, P. Saik, K. Rysbekov, M. Demydov, Rud. Geol. Naf. Zbor. 35 (2), 23-32 (2020). doi:10.17794/rgn.2020.2.3

11. S. Moldabayev, E. Aben, Intern. Journ. of Appl. Engineer. Res. 22, 10458-10464 (2016).

12. A. Khorolskyi, V. Hrinov, O. Mamaikin, Y. Demchenko, Min. of Miner. Dep., 13(4), 53-62 (2019)._doi:10.33271/mining13.04.053

13. S.K. Moldabayev, B. Rysbaiuy, in Theoretical and practical solutions of mineral resources mining (2015), pp. 49-54

14. B. Sobko, C. Drebenstedt, O. Lozhnikov, Min. of Miner. Dep. $11 \quad$ (3), 70-75 (2017). doi:10.15407/mining11.03.070

15. A. Khorolskyi, V. Hrinov, O.Mamaikin, L. Fomychova, E3S Web of Conferences 201, 01030 (2020). doi:0.1051/e3sconf/202020101030

16. S. Moldabayev, Z. Sultanbekova, A. Adamchuk, N. Sarybayev, in Proceedings of the International Multidisciplinary Scientific GeoConference Surveying Geology and Mining Ecology Management (2019) pp. 407414. doi:10.5593/sgem2019/1.3/S03.052

17. V. Falshtynskyi, P. Saik, V. Lozynskyi, R. Dychkovskyi, M. Petlovanyi, Min. of Miner. Dep. 12 (2), 68-75 (2018).doi:10.15407/mining12.02.068

18. Yu.P. Astafyev, R.V. Popov, Yu.M. Nikolashin: Upravlenie sostoyaniem massiva gornykh porod pri otkrytoy razrabotke mestorozhdeniy poleznykh iskopaemykh (Management of the state of the rock mass in the open development of mineral deposits). Kiev, Donetsk, Vishcha shk. (1986)

19. L.G. Fisenko: Ustoychivost' bortov kar'yerov $i$ otvalov (Stability of the sides of quarries and dumps). M., Nedra (1965)

20. Metodicheskie ukazaniya po opredeleniyu uglov naklona bortov, otkosov ustupov $i$ otvalov stroyashchikhsya $i$ ekspluatiruemykh kar'yerov (Methodical guidelines for determining the angles of inclination of sides, slopes of benches and dumps of open-pit mines under construction and in operation). VNIMI, Leningrad (1972)

21. M. Petlovanyi, Min. of Miner. Dep. 10 (2), 48-54 (2016). doi: 10.15407/mining10.02.048

22. E.K. Babets, V.I. Chepurnoy, S.I. Lyash: $O$ vozmozhnosti issledovaniya metodom EIPMZ sostoyaniya gornogo massiva, prilegayushchego $k$ vertikal'nym shakhtnym stvolam (On the possibility of studying the state of a rock mass adjacent to vertical shaft shafts by the EIPMZ method) 54 (NDHRI, Kryvyi Rih, 2013), pp. 53-60

23. I. Belmas, P. Kogut, D. Kolosov, V. Samusia, S. Onyshchenko, International Conference Essays of Mining Science and Practice 109,00005 (2019). doi:10.1051/e3sconf/201910900005

24. L. Krupnik, K. Yelemessov, B. Beisenov, D. Baskanbayeva, Min. of Miner. Dep. 14 (2), 103-109 (2020). doi:10.33271/mining14.02.103

25. S. Ilin, L. Adorska, V. Samusia, D. Kolosov, I. Ilina, International Conference Essays of Mining Science and Practice 109, $00030 \quad$ (2019). doi:10.1051/e3sconf/201910900030

26. O. Vagonova, T. Mormul, Y. Zakharchenko, N. Romaniuk, L. Kasianenko, Min. of Miner. Dep. 12 (4), 82-89 (2018). doi:10.15407/mining12.04.082

27. V. Buzylo, A. Pavlychenko, T. Savelieva, O. Borysovska, E3S Web of Conferences 60, 00013 (2018). doi:10.1051/e3sconf/20186000013

28. A. Gorova, A. Pavlychenko, O. Borysovs'ka, L. Krups'ka, In Mining of Mineral Deposits, (2013) 207-209. doi:10.1201/b16354-38

29. V. Popovych, O. Kuzmenko, A. Voloshchyshyn, M. Petlovanyi, E3S Web of Conferences 60, 00010 (2018). doi:10.1051/e3sconf/20186000010

30. O.M. Mandryk, L.M. Arkhypova, A.V. Pukish, A. Zelmanovych, K. Yakovlyuk, IOP Conference Series: Materials Science and Engineering 200, 012018 (2017). doi:10.1088/1757$899 X / 200 / 1 / 012018$

31. O.M. Shashenko, O.S. Kovrov, Nauk. Visn. Nat. Hirn. Univ. 6, 54-59 (2016)

32. D.V. Babets, O.O. Sdvyzhkova, M.H. Larionov, R.M. Tereshchuk, Nauk. Visn. Nat. Hirn. Univ. 2, 58-64 (2017)

33. S.I. Cheberyachko, O. Yavors'ka, D. Radchuk, A. Yavors'kyi, Solid State Phenomena 277, 232-240 (2018).doi:10.4028/www.scientific.net/SSP.277.23 2

34. Serhii Cheberiachko, Olena Yavorska, Volodymyr Hridiaiev, Andrii Yavorskyi, E3S Web of Conferences 123, $01028 \quad$ (2019). doi:10.1051/e3sconf/201912301028 